\title{
Rest at night in some solitary bees - a comparison with the sleep-like state of honey bees
}

\author{
W Kaiser \\ Institut für Zoologie der Technischen Hochschule Darmstadt, Schnittspahnstr, 3, \\ 64287 Darmstadt, Germany
}

(Received 15 November 1994; accepted 26 February 1995)

\begin{abstract}
Summary - The nightly resting behaviour of some solitary bees (Epeolus, Triepeolus, Protepeolus, Anthophora, and Melecta) was studied in the laboratory and compared with results obtained previously in honey bees. Similarities and differences in physiological and behavioural correlates of rest were found; only honey bees exhibit marked amounts of antennal motility.
\end{abstract}

Apoidea / solitary bee / Apis mellifera / rest at night / sleep / behavioural physiology

\section{INTRODUCTION}

"An object in motion always attracts the attention of children, young and old; a butterfly flitting from blossom to blossom, a locust jumping before one in the dusty road, a bee rummaging in a flower, all arouse one's interest. But naturalists, like children, cease to pay attention to insects when the latter cease their activity. Thus the interesting problem of when, where and how insects sleep has been all but neglected" (Rau and Rau, 1916).

This quotation forms the introduction to the Raus' series of lively and succint descriptions of field observations of 'sleeping' insects. It also explains why we only accidentally discovered the sleep-like state of honey bees, during neurophysiological investigations of their visual system (Kaiser and Steiner-Kaiser, 1983).
Rau and Rau used the term 'sleep' intuitively although they had also performed some simple experiments. They had discovered, for instance, that it became slowly but increasingly difficult to disturb animals which had come to rest. In addition, 'sleepers' required a certain amount of time to 'wake up' in the morning. One further important observation on solitary wasps and solitary bees was that marked individuals of certain species repeatedly returned to particular sites to 'sleep' in the company of conspecifics.

Since the term 'sleep' implies statements about the level of consciousness, it can only be strictly applied to humans. However, the term can justifiably be used for animals whose rest exhibits those objectively measurable phenomena which accompany human sleep ('sleep signs'). We therefore 
used a catalogue of criteria provided by Tobler (1984) when we studied nightly rest in the honey bee. We employed both electrophysiological techniques (electromyogram-recordings) and methods used in quantitative behavioural physiology. The results clearly demonstrate the existence of a sleep-like state in this insect (Kaiser, 1988). The studies reported here were prompted by the following question: is the sleep-like state in the honey bee, with its many parallels to mammalian sleep, a singular phenomenon restricted to this highly evolved social bee? A comparison between the nightly rest in honey bees and that of non-social, solitary bees should yield a catalogue of similarities or differences and thus an answer to this question.

This paper is the first detailed account of laboratory investigations on the nightly rest of solitary bees. The solitary bees which were studied normally spend the night either in the open or in earther burrows. The former display a bizarre resting behaviour: they attach themselves to the end of a twig only with their mandibles. Numerous field observations of this behaviour have been published (Fiebrig, 1912; Rau and Rau, 1916; Rau, 1938; Schremmer, 1955, 1961; Westrich, 1989). Preliminary reports of our work have appeared previously (Kaiser, 1990a, b; Kaiser and Steiner-Kaiser, 1991).

\section{MATERIAL AND METHODS}

\section{Experimental animals}

\section{Epeolus variegatus (Linnaeus 1758, Anthophoridae). Experiments in Portugal in June 1989}

These brood parasites were caught during the late afternoon near Costa da Caparica while feeding on Chrysanthemum coronarium, a yellow composite. The animals were brought back to the laboratory in small glass bottles containing soft tissue paper which were kept in the dark. In the dimly lit laboratory, the bees were transferred to a cage which contained small dry twigs set vertically into a piece of plasticine. Initially, the bees walked and flew around the cage. After a while they became increasingly quiet and walked up and down the twigs. Finally, each bee clamped on to the tip of a twig with its mandibles (head pointing downwards). If they were disturbed soon after clamping on, the bees left the twig. I therefore waited 15 min before transferring an Epeolus plus twig to the experimental chamber. Each animal was used only once for an experiment.

\section{Epeolus sp (Anthophoridae)}

An Epeolus 9 (species unknown) was captured on a flower in Douglas, Arizona on September 13 1989 and studied for one night.

\section{Triepeolus sp (Anthophoridae). Experi- ments in Arizona, USA, during August and September 1989}

These brood parasites were also captured while they were feeding. They were found on yellow composites (Verbesina sp) near Rodeo, New Mexico. Due to the very high ambient temperatures, the bees were brought back to the laboratory in cooled, light-tight containers.

The specimens of Triepeolus could be used for several experiments on different nights, if they were maintained in outdoor cages containing a vase with a small bunch of fresh Verbesina and Sphaeralcea (mallows). The cages were exposed to direct sunlight, but were moved at irregular intervals to shady areas, to avoid overheating the occupants. One bee (V8) survived under these conditions from September 9 to 24 .

All the Triepeolus specimens could find their resting sites in complete darkness. In the early evening, they were taken out of their cages and transferred individually to glass beakers which contained small vertically oriented twigs. The beakers were placed in complete darkness. Usually, the bees had clamped on to the tip of a twig (head pointing downwards) within $5 \mathrm{~min}$. 


\section{Protepeolus singularis (Anthophoridae)}

One female and 1 male specimen of this brood parasite were caught near Rodeo, NM on August 241989 and August 271989 respectively. They were handled in the same way as Triepeolus.

All these solitary bees (Epeolus, Triepeolus and Protepeolus) normally spend the night in the open, clamped onto a twig with their mandibles.

\section{Anthophora fulvitarsis (Brullé) and Melecta aff tuberculata (Lieftinck) (both Anthophoridae). Portugal, June 1989}

$M$ tuberculata is a brood parasite (cuckoo) of $A$ fulvitarsis. Females of both species were captured in the evening at a loess cliff. The clift faces eastwards and was covered with hundreds of entrances to the nest burrows of Anthophora. Both the solitary bee Anthophora and its cuckoo spend the night in the burrows, which Anthophora digs. The site is located near Alfarim, southeast of Lisbon and around $4 \mathrm{~km}$ from the Atlantic coast. The animals were brought to the laboratory (see Epeolus, above) and each was studied for one night.

\section{Experimental apparatus}

The behaviour of the bees was observed in total darkness with the aid of an infrared-sensitive video camera (Panasonic CD22) connected to a timelapse recorder (Panasonic NV-8050). Four light-emitting diodes (LD 271, maximum emission at $950 \mathrm{~nm}$ ) served as the infrared source. Two pieces of opaque acrylic glass, located between the diodes and the animal, provided a uniformly illuminated background. The camera thus viewed the bee in silhouette in front of a light background.

In the case of Epeolus, Triepeolus and Protepeolus, the twig, together with its attached bee, was mounted in front of the opaque plates. The original spatial orientation of the twig in the cage was usually preserved. Exceptions have been noted in the legends of the appropriate figures.

Individual specimens of Melecta and Anthophora were placed in a rectangular transparent glass-walled cuvette for observation at night. The narrow sides and the floor of the cuvette were made of Plexiglas and covered with thin balsa wood; the lid, also of Plexiglas, had holes for ventilation. The space available to an animal inside the cuvette measured $44 \times 33 \times 16 \mathrm{~mm}$.

\section{Data analysis}

All the video tapes were evaluated on a TV-monitor during playback. When greater temporal resolution was required, the tapes were played back at the original recording speed (the timelapse factor during continuous recording was either 4 or 12) and measurements were made on single frames.

\section{RESULTS}

\section{Epeolus, Triepeolus and Protepeolus}

\section{Laboratory experiments}

Under moderate room-light conditions, the clamping-on behaviour could be observed directly. The bees crawled up the twigs, went over the top and then clasped the twig, at or near its tip, with their mandibles (fig 1). Usually, they then raised their legs from the substrate and began to intensively groom their bodies (fig 2b). Grooming was followed by an observable change in the bees' behaviour: if the animals were disturbed soon after they had clamped on to a twig, they tended to release their hold and started moving down the twig. This tendency was much weaker after a grooming session. Soon after the bees had clamped on, and after grooming, the antennae pointed forward and lay very close to, or even touched, the twig (figs $1,2 a$ ). The antennae of Triepeolus and Protepeolus then moved very slowly in an arc towards the animals' dorsal surface (fig 2c, d). Their final resting position was independent of the spatial orientation of the animals and of gravity: the same antennal position relative to the head as in figure $2 \mathrm{~d}$ was reached by animals, 

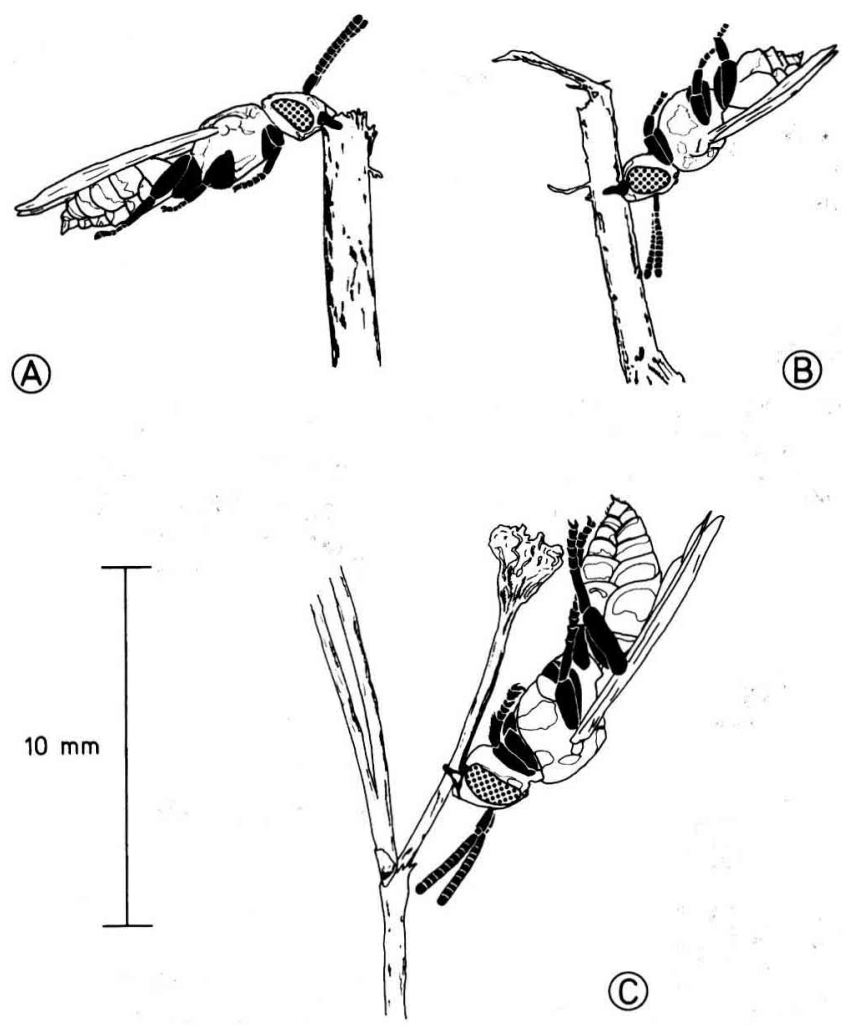

Fig 1. Resting postures in cuckoo bees which are clamped on to the upper ends of dry twigs. A: Paranomada velutina, B: Triopasites penniger $\sigma^{\prime}$, C: Nomada sp O'. The animals were captured on flowers. In the evening, they were placed in a small cage which contained upright, dry twigs. The bees clamped on to the twigs and adopted the positions shown here. Drawings from colour photos (Arizona 1989).

which clamped on to vertical twigs with their heads pointing downwards.

Epeolus also touched the twig with its antennae or held them close to it in the evening, after clamping on, and in the morning, just prior to releasing its mandibles. During the night, however, the antennae moved to a dorsolateral position. After they had reached their final resting position, they remained motionless. This was also true for Triepeolus and Protepeolus. However, all animals made antennal movements during grooming and other large body movements.

The position of the head remained unchanged throughout the night, indicating that the mandibular muscles maintained their tone. The thorax and abdomen, on the other hand, slowly adopted different posi- tions, indicating a decrease of tone in other muscles (compare fig $2 a$ with $2 d$ ).

The upper curve in figure 3 demonstrates the time course of changes in the spatial orientation of the thorax of an $E$ variegatus (P11). The position of the thorax was measured with a protractor attached to the screen of the monitor. The bee had clamped on to the end of a twig in a spatial orientation approximately corresponding to that in figure 1c. The angle $\alpha$ was defined as follows: the angle between a vertical reference line (direction of gravity) passing through the midpoint of the bee's neck and the line connecting this point with the scutellum (dorsal landmark on the thorax; compare also with the inset of fig 6 below, where the reference line is horizontal). 

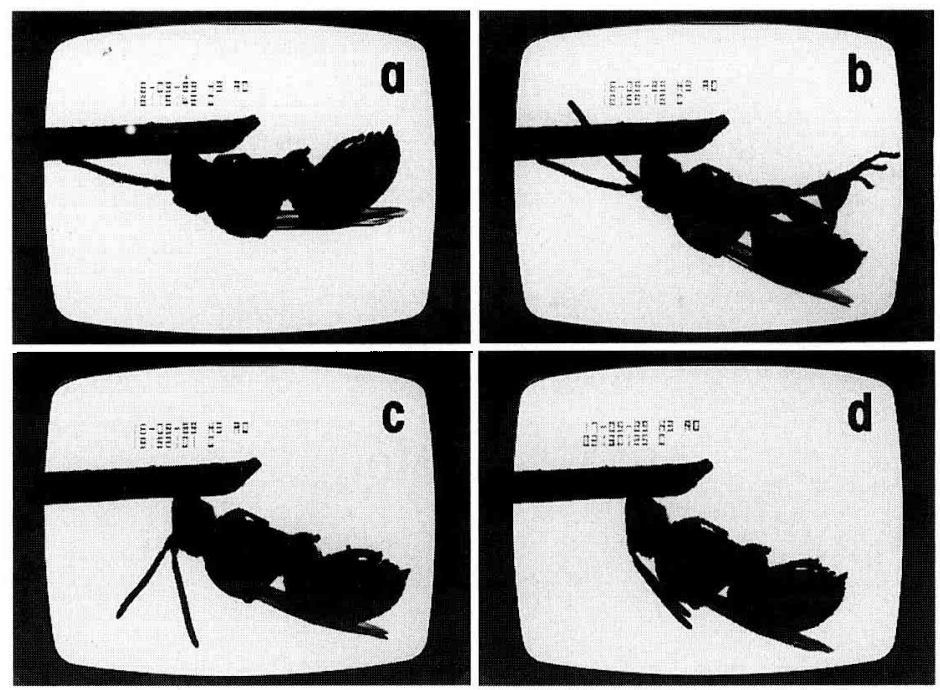

Fig 2. Triepeolus sp $\sigma^{7}(\mathrm{~V} 8)$, photos of images on the video monitor. a: $18.15 \mathrm{~h}$, shortly after the bee was introduced into the recording apparatus; $\mathbf{b}: 18.59 \mathrm{~h}$, grooming; $\mathbf{c}: 19.52 \mathrm{~h} ; \mathbf{d}: 03.30 \mathrm{~h}$. The twig visible at the left of each frame was vertically oriented when the bee clamped on. The bee's head then pointed downwards and the ventral side of its thorax rested on the twig's tip. The twig was subsequently mounted horizontally in the apparatus (bee's ventral surface facing upwards) to make changes in muscle tone visible. This did not disturb the animal: the longest rest episode lasted $4.6 \mathrm{~h}$ when the twig was horizontal (this experiment) and $4.4 \mathrm{~h}$ when the twig was vertical (see table I).

Further movements that bees performed after having clamped onto a twig were pumping abdominal movements. These occurred in bursts which followed one another at more or less long intervals. The lower curve in figure 3 represents the time course of the duration of ventilatory cycles (bursts plus intervals) in the bee P11. The number of pumping movements per burst, and the duration of individual bursts, remained relatively constant for long periods during the experiment. For the interval between 4.15 and $4.30 \mathrm{~h}$, there were, on average, 85.5 pumping movements per burst and the average burst duration was $27.2 \mathrm{~s}$. After approx $6.30 \mathrm{~h}$, the number of pumping movements per burst decreased and the burst duration increased.

Each burst of ventilatory movements was preceded by a succession of abdominal extensions. These abdominal extensions were accompanied by an elevation of the thorax and abdomen, when the animals rested in postures like those shown in figures 1 and 2. After the end of each series of abdominal pumping movements, the thorax and abdomen slowly sank down again. The time course of the size of the angle $\alpha$ in figures $3,5 \mathrm{~B}$ and 6 (below) does not show the dynamic changes induced by ventilation, since $\alpha$ was always measured at the end of a ventilatory cycle, before the abdomen stretched. Figure 3 shows that ventilation became slower as the bee's body sank downwards. There was a spontaneous increase in ventilatory frequency around $4.30 \mathrm{~h}$.

Of the solitary bees I studied in the laboratory, the animal which yielded the results for figure 3 showed the least motility during 


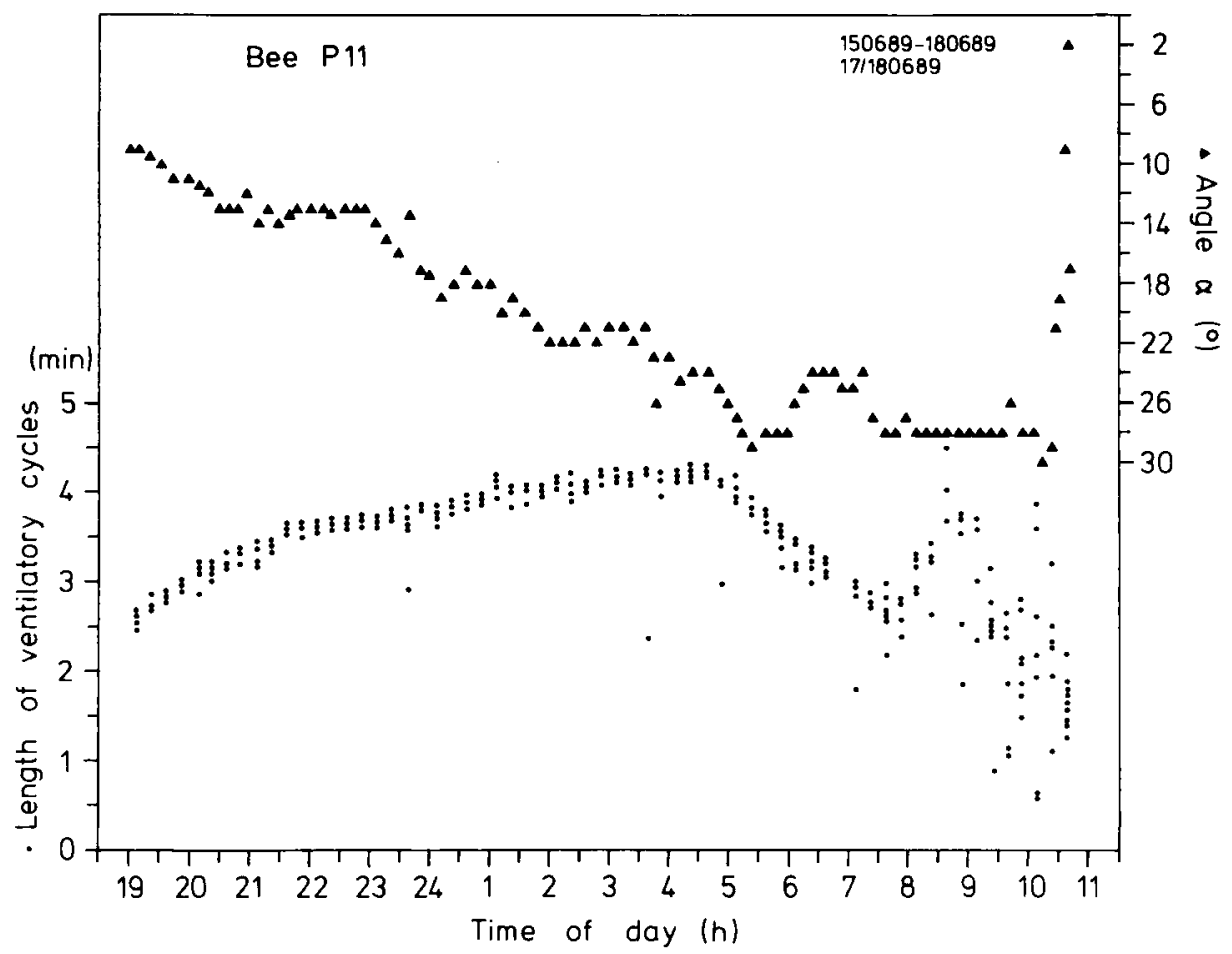

Fig 3. Length of ventilatory cycle and body angle $\alpha$ as a function of the time of day in $E$ variegatus $\rightarrow(P 11)$. Cycle length was defined as the time interval between the start of 2 successive bursts of ventilatory activity. Individual cycle lengths were measured during 15-min intervals. For the sake of clarity, all values obtained within each 15-min interval have been plotted at its mid-point. The bee left the twig at $10.46 \mathrm{~h}$.

the night. During an interval of $14.6 \mathrm{~h}$, it displayed neither large body movements nor grooming, although the ambient temperature $\left(24.5^{\circ} \mathrm{C}\right)$ was higher than under natural conditions. The longest episode of rest (absence of larger body movements and grooming) of the bee in figure 4 lasted $3 \mathrm{~h}$ and occurred late at night. Figure 4 illustrates a further typical result: episodes of grooming (of head, body and antennae) were longest during the transition from activity to rest, and most frequent during the transition from rest to activity. The longest grooming episode in figure 4 lasted $23.4 \mathrm{~min}$ !
The forms of the curves in figure 4 are typical for the results obtained from all bees that clamped on; however, there were differences in the absolute values. The major results from these experiments are summarized in table 1 .

The experiment shown in figure 5 was prompted by the question whether clamping-on is a necessary precondition for reaching a stable state of rest. In the early evening of September 15 1989, a Triepeolus, V8, was placed in a transparent cuvette lined with balsa wood (inner dimensions $22 \times 16 \times$ $6 \mathrm{~mm}$ ). As figure 5A shows, the animal did not enter a prolonged state of rest but dis- 


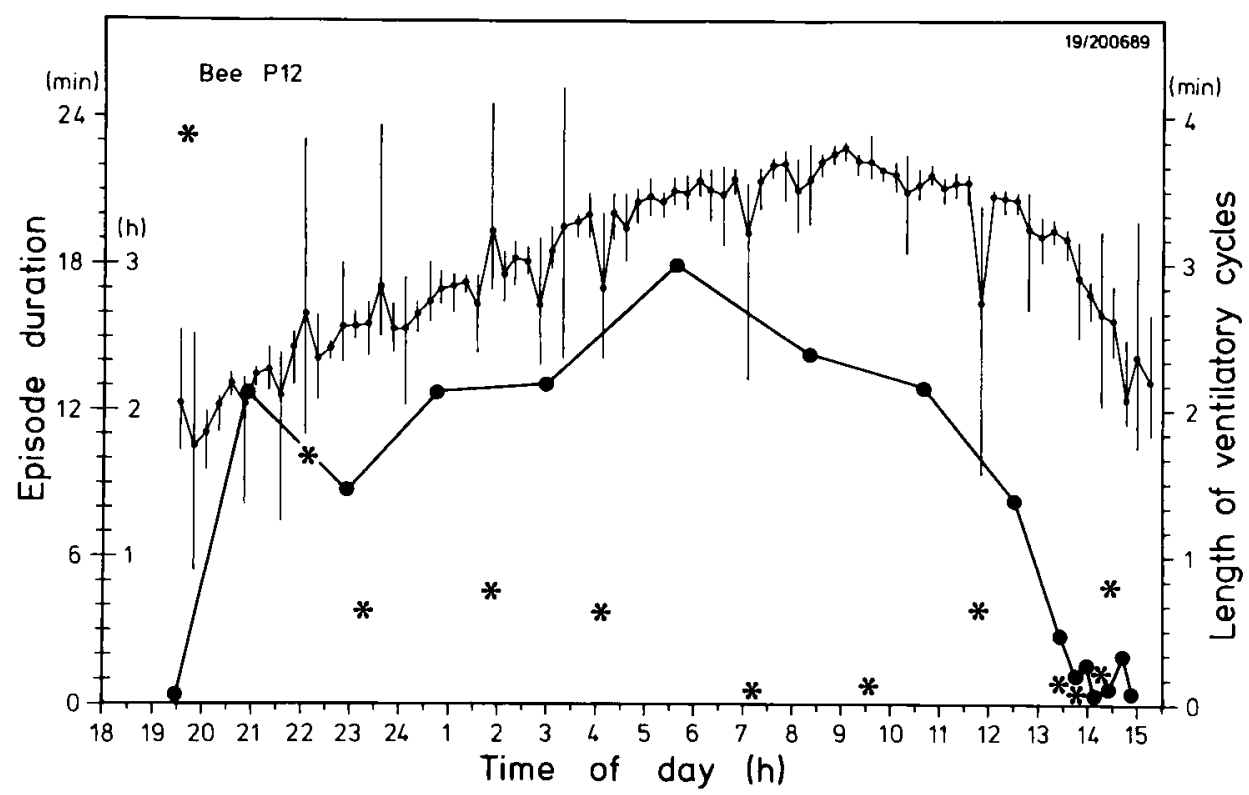

Fig 4. Time course of the episode durations of rest and grooming (large filled circles and asterisks) and of the length of ventilatory cycles (uppermost curve) in $E$ variegatus $(P 12)$. The values for individual rest episodes have been plotted at the mid-point of the respective episode. The points on the ventilatory cycle curve represent mean values for a 15-min interval; they have been plotted at the mid-point of the respective interval. The vertical bars join the extreme values measured in each interval. The animal had clamped on to the end of a vertical twig (head pointing downwards) and the ventral side of its thorax rested on the twig's tip. It left the twig at $15.23 \mathrm{~h}$. The experiment was conducted in continuous darkness at $24^{\circ} \mathrm{C} .0$ rest $(\mathrm{h}) ;^{*}$ grooming $(\mathrm{min})$.

played instead a variety of behaviour (locomotion, grooming and rest). I terminated the experiment at $22.06 \mathrm{~h}$. The room lighting was switched on and the bee was transferred to a beaker containing a vertically oriented twig. At first, the bee walked animatedly around in the beaker, but, within $7 \mathrm{~min}$, it had clamped on to the tip of the twig. Subsequently, neither carrying the twig around in the illuminated laboratory, nor mounting it into the experimental apparatus, prompted the bee to release its hold. The animal's behaviour during the rest of the night is shown in figure 6 . These subsequent results were again obtained in total darkness. To compare the bee's behaviour in the cuvette (fig 5A) with the behaviour one could expect it to show at the same time of day, but while clamped on to a twig, the data from the first half of the next night are presented in figure $5 B$. There are 3 major differences between figures $5 \mathrm{~A}$ and $5 \mathrm{~B}$ : (1) the bee only walked around in the cuvette; it never released its hold on the twig; (2) long-lasting grooming episodes occurred repeatedly in the cuvette; on the twig, the bee groomed intensively only during the first hour of the experiment and subsequently only briefly and sporadically; and (3) between approximately 21 and $22 \mathrm{~h}$, rest in the cuvette was almost negligible, whereas it occupied the entire interval on the twig. 


\section{'Field experiments'}

The data presented above were obtained under constant laboratory conditions. The following data were derived from 2 'field experiments'. An optical bench which carried the video camera, the infrared light source and the holder for the twig plus bee was set up under the open sky in the garden outside the laboratory at each location. The experimental animals were thus exposed to the naturally-occurring variations in light intensity, air temperature, and humidity.

\section{Epeolus $s p(P 17)$, Portugal,} June 26-27, 1989

The bee clamped on to the tip of a vertically-oriented twig (head pointing downwards) at $19.45 \mathrm{~h}$; the ventral side of the

Table I. Ambient temperature and results of laboratory investigations on the nightly resting behaviour of solitary bees.

Animal

\section{Ambient temperature} ( ${ }^{\circ}$ )

\section{Longest \\ ventilatory \\ cycle (min)}

Longest
rest
episode

(h)
Start of activity

(h) *

\section{Epeolus}

P11 $9.7 \mathrm{~mm}^{\mathrm{a}}$

$\mathrm{P} 12 \%, 7.3 \mathrm{~mm}$

P14 O", $5.9 \mathrm{~mm}$

P15 O

P16 O

V10 9

Protepeolus

V3 $9,9.6 \mathrm{~mm}$

V5 ơ, $9.2 \mathrm{~mm}$

\section{Triepeolus}

V8 O', $8.4 \mathrm{~mm}$

V8

V8

V9우

\section{Anthophora}

P1 옹 $17.5 \mathrm{~mm}$

P2 우

P8우

\section{Melecta \\ P3 0 , $19.9 \mathrm{~mm}$}

24.5

24.0

25.3

27.0

28.0

22.5

21.5

20.5

21.5

22.5

23.0

23.0

22.3

21.2

24.5

20.7

22.2

$4.2^{b}$
$3.8^{b}$
$2.7^{b}$
$2.6^{b}$
$2.0^{b}$
$5.4^{b}$

$10.0^{c}$

$19.0^{\mathrm{C}}$

$6.1^{\mathrm{c}}$

$3.4^{b}$

$3.8^{b}$

$6.0^{b}$

$8.8^{c}$
$16.6^{c}$

1.3

3.0

1.5

$06 \cdot 17$

08:30

07:41

$\begin{array}{rrr}8.0^{c} & 2.1 & 08: 15 \\ 11.7^{c} & 2.9 & 07: 06\end{array}$

All experiments were performed in continuous darkness. ${ }^{a}$ Body length without antennae; $b$ mean values from 15 min intervals; ${ }^{c}$ mean values from 30 min intervals; ${ }^{d}$ the bee was transferred to a cage in the morning where it became active in direct sunlight. * Approximate local time of sunrise in Portugal (animals P1-P16): $06.30 \mathrm{~h}$; in Arizona (animals $\mathrm{V} 3-\mathrm{V} 10): 06.10 \mathrm{~h}$. 

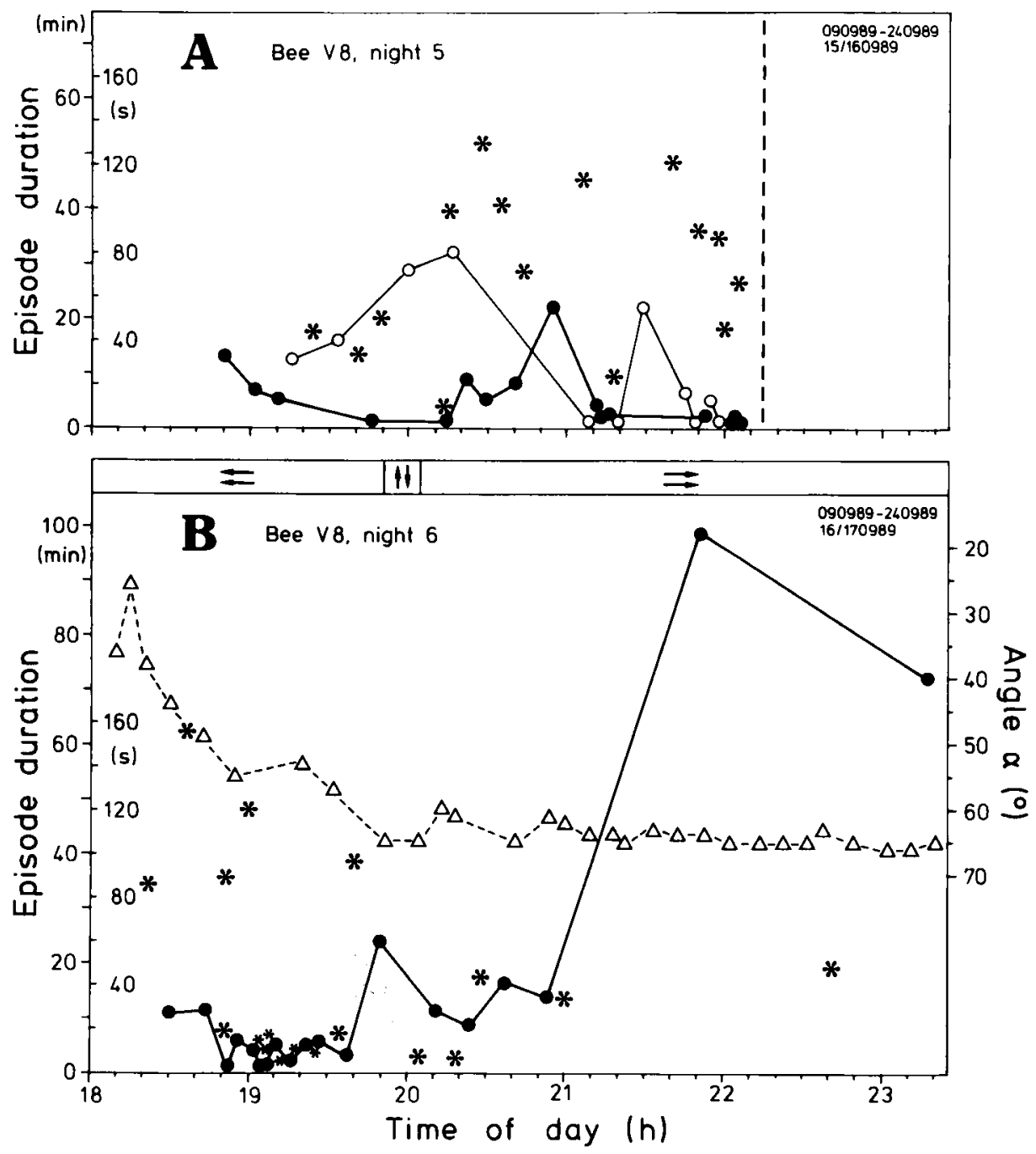

Fig 5. Resting behaviour in Triepeolus sp (V8). A: in a cuvette, B: clamped onto a twig, in the evening of the following day. The bee clamped on to the twig while it was vertically oriented. The experiment was performed with the twig in a horizontal position (see inset of fig 6 in which the angle $\alpha$ is also defined). The double arrows in $\mathbf{B}$ represent antennal positions during the respective time intervals. Arrows to the left: see figure 2a, arrows pointing up and down: see figure $2 c$; arrows pointing to the right: see figure 2d. There was a smooth transition from one antennal position to the next. Antennal positions which were maintened for less than $60 \mathrm{~s}$ (during and after grooming episodes) were not included. Measurements during both nights were made in continuous darkness and at a temperature of approx $22^{\circ} \mathrm{C}$. Further details of experiment $\mathbf{B}$ are given in table I. rest (min); $O$ or $\Delta$ locomotion (min); * grooming (s). 


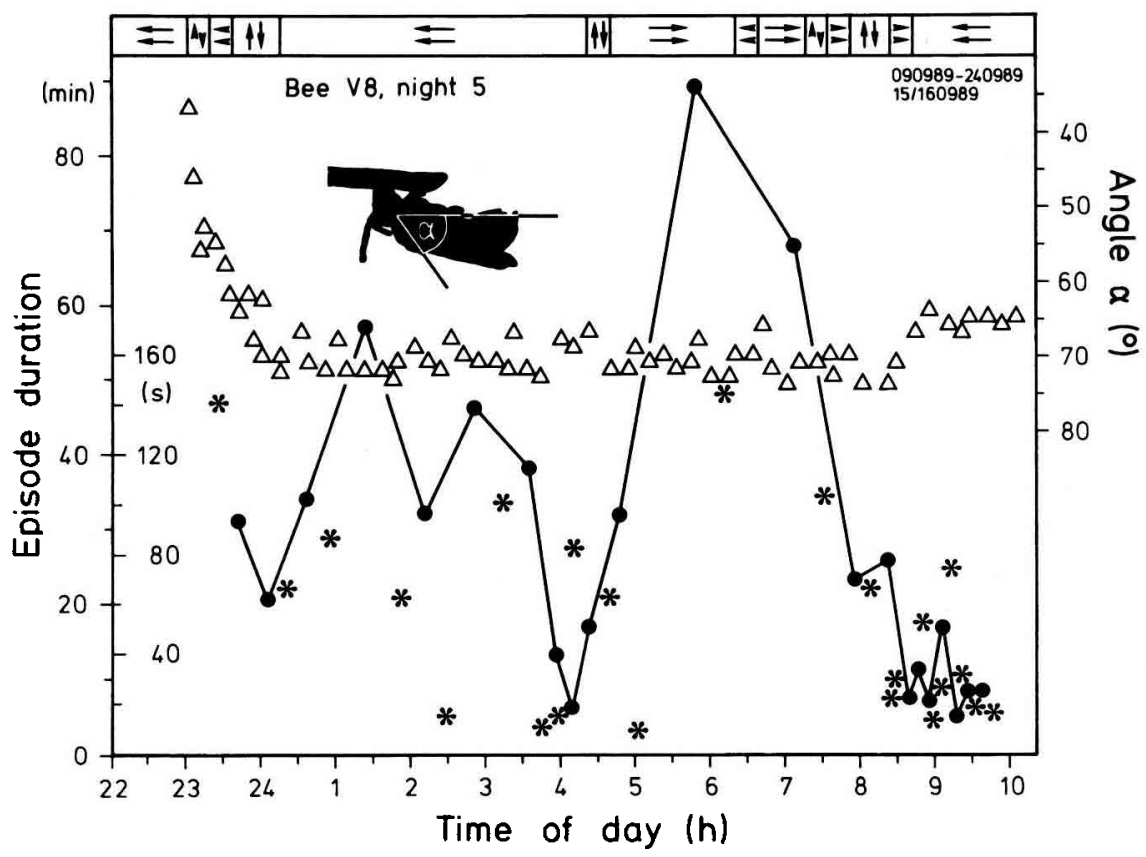

Fig 6. Resting behaviour in Triepeolus sp $O^{x}(\mathrm{~V} 8)$ - continuation of the experiment shown in fig 5A. The animal had now clamped on to a vertical twig which was then mounted horizontally. The significance of the arrows is explained in the caption of figure 5. $\alpha$ was measured on the monitor. rest $(\min ) ; *$ grooming (s).

animal's thorax rested on the end of the twig. The original orientation of the twig was maintained when it was mounted on the optical bench. Air temperature decreased progressively during the night and reached its minimum of $15.8^{\circ} \mathrm{C}$ at $5.05 \mathrm{~h}$. This value remained constant till sunrise, at $6.30 \mathrm{~h}$. In the morning, around $10.00 \mathrm{~h}$, the weather was clear and sunny, and the air temperature had reached $23.3^{\circ} \mathrm{C}$. The bee, still clamped on, was in the shade of the laboratory building. It displayed occasional body movements and breathed more quickly than during the night (the duration of one ventilatory cycle was $0.86 \mathrm{~min}$ as compared to $9.1 \mathrm{~min}$ at the minimum temperature). A few minutes later, the bee was in direct sunlight and, a few minutes after that, it flew away. The evaluation of the data yielded curves very similar to those in figure 4; only the absolute values differed. The longest rest episode lasted 6.6 $h$, the longest ventilatory cycle $9.1 \mathrm{~min}$. The descending flanks of the curves were shifted towards earlier times of day.

One event, which occurred late at night, is worth mentioning. The resting bee was visited by an ant. As the ant crawled up the twig, it encountered the bee's head. The bee reacted by making very pronounced defensive leg movements and the ant moved away and walked down the twig soon after.

Triepeolus sp (V8), Arizona, September 23-24, 1989

The resting behaviour of this animal had already been studied in the laboratory; the experiment was conducted similarly to the 


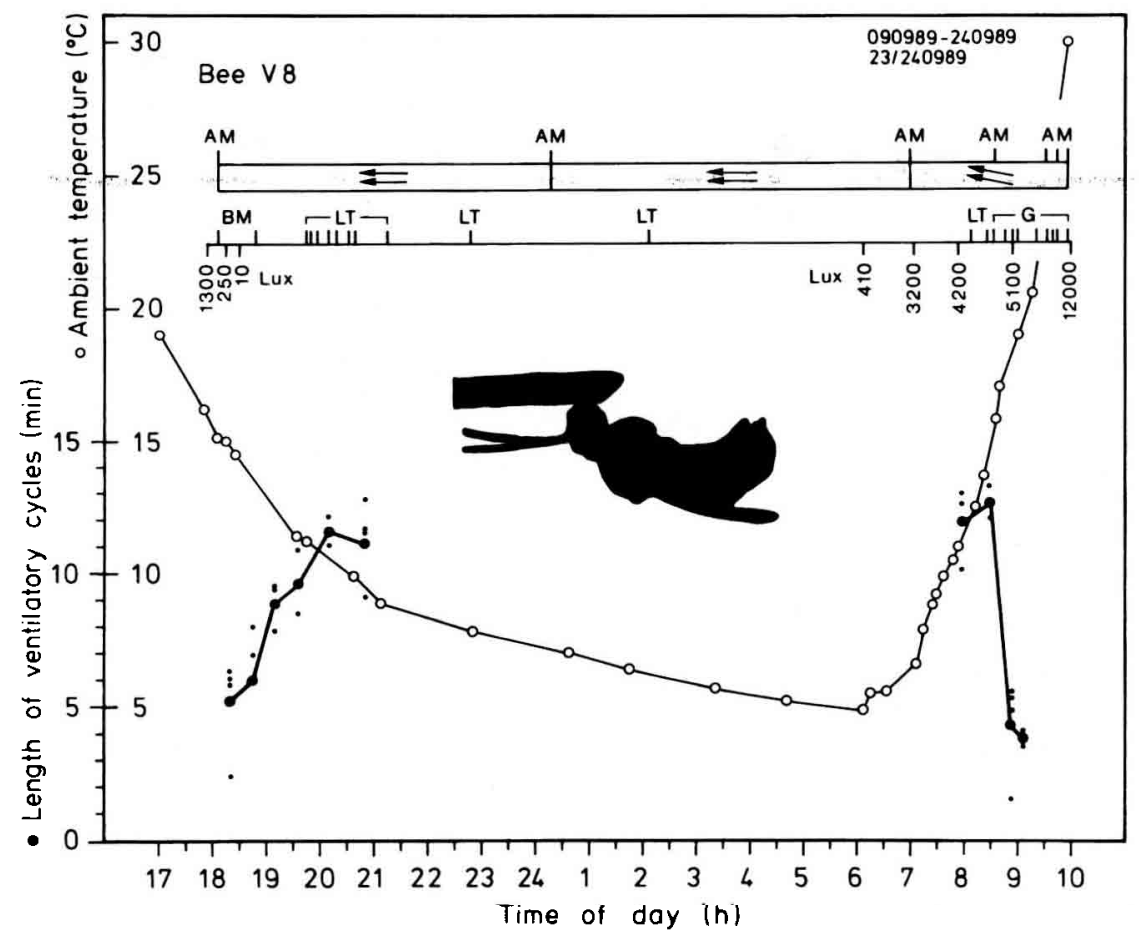

Fig 7. Time course of the length of ventilatory cycles, ambient temperature, and light intensity, during a 'field experiment' with Triepeolus sp $\mathrm{O}^{\mathrm{T}}(\mathrm{V} 8)$. AM: antennal movements, BM: body movements, LT: leg twitches, G: grooming. Large filled circles: mean values of ventilatory cycle length during 15 min intervals, calculated from individual values represented by the small filled circles. Open circles: ambient temperature. Horizontal arrows: antennal position as shown in the inset, tilted arrows: antennae touching the twig. The bee released its hold on the twig at $9.59 \mathrm{~h}$ (sunrise: approx $6.10 \mathrm{~h}$ ).

one just described. However, the spatial orientation of twig and animal was different. After the animal had clamped onto the twig when this was in a vertical position, the twig was mounted horizontally in the apparatus so that the dorsal surface of the animal faced the ground (see fig 2 and inset to fig 7). In addition, in Arizona, the nightly minimum temperature $\left(4.9^{\circ} \mathrm{C}\right)$ was much lower than in Portugal and also lower than the nightly minimum at the valley location where the bee had been captured $\left(10.4^{\circ} \mathrm{C}\right)$. This latter difference is due to the high altitude of the Research Station.
The low ambient temperature led to a surprising result: the animal showed no discontinuous resting ventilation after the temperature dropped below approximately $9^{\circ} \mathrm{C}$, and it only resumed breathing in this fashion in the morning when the temperature rose beyond $10^{\circ} \mathrm{C}$ (fig 7 ). The bee's antennae also assumed an unexpected resting position during the night. Instead of adopting the position typical of long rest episodes in the laboratory (fig 2d), the antennae remained in the position shown in the inset in figure 7 during most of the night. This result was unexpected in view of the fact 


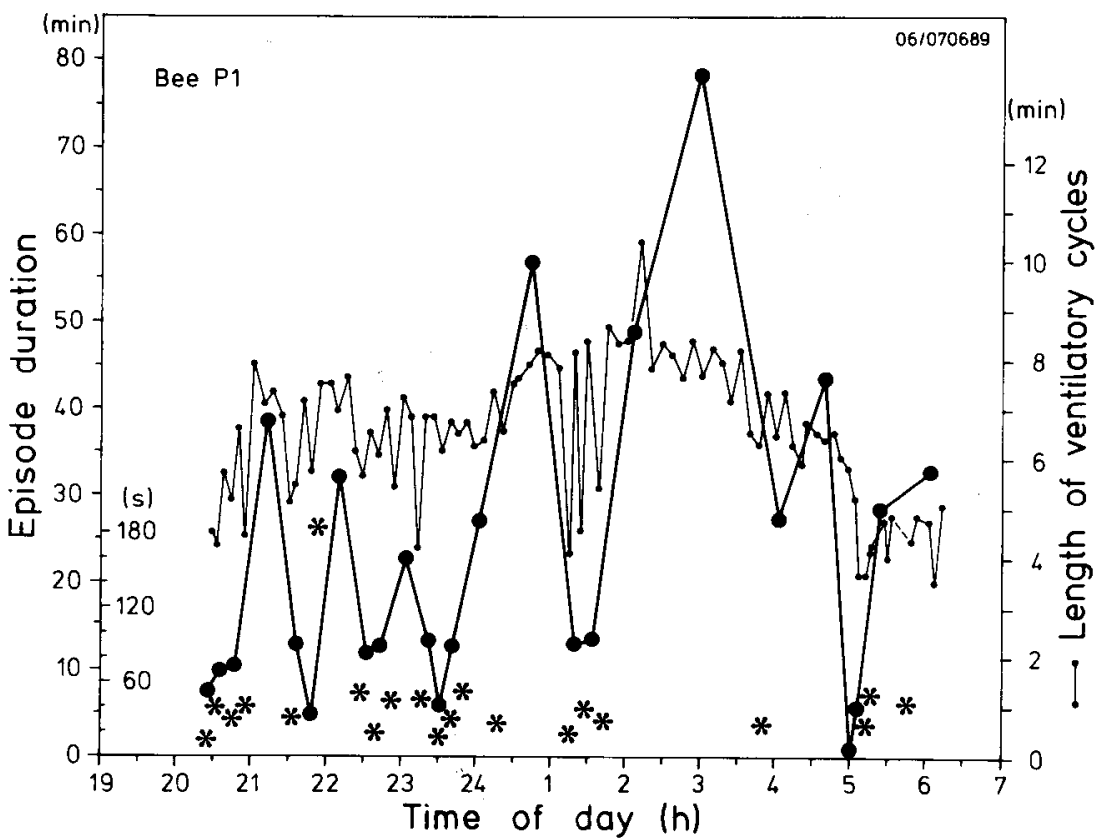

Fig 8. Behaviour of $A$ fulvitarsis $9(\mathrm{P} 1)$ during one night in a cuvette. Observations were made in continuous darkness. Table I provides further details. rest $(\mathrm{min}) ; *$ grooming $(\mathrm{s})$.

that the duration of the bee's longest rest episode $(14.5 \mathrm{~h})$ was much greater than that found under laboratory conditions in the same animal (see table I). A new phenomenon appeared at low temperatures: leg twitches. Like Epeolus in Portugal, Triepeolus released its hold on the twig only after it became exposed to direct sunlight (ambient temperature approx $30^{\circ} \mathrm{C}$ ).

\section{A fulvitarsis, $M$ tuberculata}

\section{Observations at nest sites of A fulvitarsis}

Both $A$ fulvitarsis and its brood parasite, $M$ tuberculata, spend the night in burrows dug by $A$ fulvitarsis. On the observation days (June 8, 10 and 14,1989), the weather was clear and sunny; only females were observed.
Evening observations. Several A fulvitarsis returned from foraging flights after sunset (eg, return time $21.06 \mathrm{~h}$, sunset $20.50 \mathrm{~h}$ ). The temperature in the burrows after sunset was higher than the ambient temperature outside (burrow: $19.9^{\circ} \mathrm{C}$; air temperature: $14.8^{\circ} \mathrm{C}$ ). The animals rested with their heads directed towards the burrow entrance (observation in 3 bees).

Morning observations. A few specimens of $A$ fulvitarsis were seen returning to their burrows at $6.13 \mathrm{~h}$, well before sunrise $(6.35$ h). The air temperature at this time was $12.7^{\circ} \mathrm{C}$, while the temperature in the burrows was $17.4^{\circ} \mathrm{C}$. Several $A$ fulvitarsis could also be seen sitting at their nest entrances before sunrise, but they only flew off after they had sat in direct sunlight for a while and had groomed themselves extensively. 
Flying $M$ tuberculata were first encountered at $7.40 \mathrm{~h}$, when the air temperature was $17.4^{\circ} \mathrm{C}$.

\section{Laboratory experiments}

Figure 8 represents the results obtained by observing a female specimen of $A$ fulvitarsis (P1) which spent the night in a cuvette at an ambient temperature of $22.3^{\circ} \mathrm{C}$. The animal rested on the floor of the cuvette. The longest rest episode (interval without head, body, or grooming movements) occurred late in the night, and had a duration of $1.3 \mathrm{~h}$. The entire experiment was performed in complete darkness, but the bee became active at $6.17 \mathrm{~h}$, before sunrise $(6.30 \mathrm{~h})$. The animal displayed discontinuous resting ventilation at night, with the longest ventilatory cycle also occurring late at night. The stepwise abdominal elongation before the start of ventilatory movements, displayed by Epeolus, Protepeolus, and Triepeolus, also occurred in $A$ fulvitarsis. Grooming movements were absent over a long interval late at night.

Two phenomena which accompanied the nightly rest of this bee are not shown in figure 8: a decrease in leg muscle tone (the animal gradually sank onto the floor of the cuvette during longer rest episodes) and tarsal twitching. In addition, during long rest episodes, the antennae adopted characteristic postures: after being initially held parallel to the floor of the cuvette, they gradually sank down until the flagella were approximately parallel to the frons of the animal. No further antennal movements were observed until a bout of grooming or a large body movement occurred. The same applied to Melecta (see below).

Observations on 2 further female $A$ fulvitarsis ( $\mathrm{P} 2$ and $\mathrm{P} 8$ ) yielded results very similar to those in figure 8 , but rest was more pronounced: longest rest episode: $3.0 \mathrm{~h}$; longest average ventilatory cycle: $16.6 \mathrm{~min}$ (see table I). Both animals became spontaneously active early in the morning, but only after sunrise (see table I). Two female specimens of $M$ tuberculata, which where observed individually on 2 nights, also in complete darkness, behaved very much like their hosts: they also rested on the floor of the cuvette (ventral side down), exhibited long episodes of rest which were accompanied by slower breathing and reduction in leg muscle tone, as well as spontaneous early return to activity. However, the 2 species differed clearly with respect to antennal posture: the antennae of $M$ tuberculata moved slowly backwards during longer rest episodes and finally came to lie in a dorsolateral position. Further details of these experiments are provided in table $\mathrm{I}$.

\section{DISCUSSION}

As long ago as 1916, Rau and Rau suggested investigating the physiological processes accompanying 'sleep' in insects. To date, very few scientists have responded. The most recent studies are on cockroaches (Tobler, 1983; Tobler and Neuner-Jehle, 1992) and honey bees (see below).

The work reported here was initiated by our interest in the question of whether the physiological processes during the nightly rest of the honey bee (Kaiser, 1988) differ from those of related, less highly developed (solitary) bees. In this paper nightly rest in solitary bees is studied for the first time using methods of quantitative behavioural physiology. A valid basis for comparison is provided by the fact that most of the experiments with solitary bees (like those on the honey bee) were performed under constant laboratory conditions and at a temperature higher than $20^{\circ} \mathrm{C}$. Both similarities and differences have emerged.

\section{Similarities}

\section{Resting sites}

Both honey bees and solitary bees seek out specific places at which they spend the 
night. Pollen foragers of the honey bee (only this type of worker bee has been studied so far) rest in the hive, usually either on the combs, outside the brood area, or on the hive walls (Sauer and Kaiser, 1995). The fact that these animals do not participate in the generation of heat in the hive shows that they are truly resting (Kaiser, 1988).

The biological significance of the fact that some solitary bees clamp on to the end of a twig may be increased protection against enemies. In this position, a bee could be mistaken for part of the plant, and it would also be less accessible to ants (see Results). Both hives and nest burrows offer honey bees and $A$ fulvitarsis, together with its brood parasite $M$ tuberculata, respectively, increased protection at night.

\section{Phenomena accompanying rest at night}

In both honey bees (Kaiser, 1988) and the species of solitary bees investigated here, observations under constant laboratory conditions revealed, at night, the presence of processes which have similar time courses. (1) There was a progressive increase in the duration of rest episodes, with maximum values occurring late at night. (2) The ventilatory frequency fell to a minimum late at night (honey bees; unpublished data). (3) The tone in certain muscles decreased. (In the solitary bees, changes in the orientation of the whole, or parts, of the body were interpreted as decreases in muscle tone, if these changes occurred gradually and in the direction of gravity. In honey bees, a comparison between gradual changes in head position and the amplitude of neckmuscle myograms proved that there was a progressive loss of tone.) (4) The animals adopted characteristic antennal postures.

The following phenomena also accompanied rest at night in all species: twitching movements of the tarsi, and increased grooming during the transitions from activity to rest and rest to activity. The phenomena
(1) to (4) indicate that solitary bees exhibit a progressive increase in the depth of rest at night. This conclusion is based upon a comparison of the present results with those obtained in the honey bee. In this animal, the time course of the nightly reaction threshold (fig 9 in Kaiser, 1988) agrees well with the time courses of the 4 parameters described above.

\section{Differences}

\section{Motility during rest at night}

Even at $25^{\circ} \mathrm{C}$, a temperature which, at night, is normally available only to honey bees, solitary bees exhibited much less motility than their social relatives. The longest rest episode (absence of head and body movements) measured to date in honey bees at $25^{\circ} \mathrm{C}$ is $13.4 \mathrm{~min}$ (Kaiser, 1988). At almost the same temperature $\left(24.5^{\circ} \mathrm{C}\right)$, the longest rest episode measured in $A$ fulvitarsis (P8) was $1.5 \mathrm{~h}$. At this temperature, $E$ variegatus (P11) displayed a rest episode whose duration was $14.6 \mathrm{~h}$ ! Motility during the night clearly differs between honey bees and the solitary bees I have studied. This becomes even more obvious when one compares the amount of antennal immobility. The longest episode of antennal immobility measured to date in honey bees is $4.1 \mathrm{~min}$ (Kaiser, 1988). In the solitary bees, the intervals without antennal movements lasted for hours late at night. It is likely that, under natural conditions, honey bees and the solitary bees which spend the night completely in the open differ even more markedly with respect to their motility during rest. This assumption is supported by the results of the 'field experiments' on $E$ variegatus and Triepeolus sp (V8). A fulvitarsis has not been investigated experimentally under near-natural conditions, to date. This species, under natural conditions at night, probably does not cool down to 
the same extent as Epeolus, Triepeolus, and Protepeolus, for the following reasons: (1) A fulvitarsis spends the night in earthen burrows which are warmer than the air outside; (2) it is considerably larger than the other 3 species; (3) it has thick 'fur'. A fulvitarsis is a heterothermic insect (see Results; observations at nest sites). This species may therefore even actively maintain its body temperature at a particular value during the night. Stone (1993) has demonstrated, for A plumipes, that high body mass is advantageous in the generation of higher thoracic temperatures when the ambient temperature is low.

A fulvitarsis might therefore display approximately the same motility at night under natural conditions as it did in the laboratory at a temperature of $21-25^{\circ} \mathrm{C}$. But even at these temperatures, this solitary bee displayed much less motility at rest than the honey bee (table I). $M$ tuberculata, the brood parasite of $A$ fulvitarsis, is about the same size as its host and the factors mentioned for its host probably are relevant to it, too.

\section{The relationship between resting time and light intensity}

Honey bees continue to forage after sunset and they become active in a dark hive in the morning. When kept in continuous darkness in the laboratory, they display a circadian (endogenous) rest-activity rhythm (see Kaiser, 1988, for review). The solitary bees which clamp on to a twig to rest behave quite differently. They can adopt this posture when the weather starts becoming cloudy (Westrich, 1989, p 124, 267, Kaiser, unpublished data - Triepeolus sp). In the 2 'field experiments', both $E$ variegatus and Triepeolus sp became active only after they had been exposed to direct sunlight, despite the fact that the ambient temperature in the shade was more than $20^{\circ} \mathrm{C}$. It thus seems likely that, under natural conditions, these animals do not become active in the dark. In the laboratory, the animals were observed in continuous darkness and at unnaturally high temperatures. Under these conditions, they became active (released their hold on the twig) either late in the morning (eg, P11, fig 3 ) or in the early afternoon (eg, P12, fig 4); table I provides further examples. The resumption of activity might have been triggered either by the depletion of their energy reserves or by an internal clock. These hypotheses are presently under investigation.

In contrast to the bees which clamp on, $A$ fulvitarsis, like honey bees, can fly after sunset and they also become active in their burrows before sunrise. In the laboratory, in constant darkness, they also resumed activity early in the morning (fig 8 , table I).

\section{Ambient temperature at night}

Honey bees spend the night in the hive, where temperatures around $25^{\circ} \mathrm{C}$ are commonly encountered outside of the brood area (Hess, 1926). This temperature is well above $12^{\circ} \mathrm{C}$, the 'chill coma' limit in honey bees (Lighton and Lovegrove, 1990, Apis mellifera ligustica). Below an ambient temperature of $12^{\circ} \mathrm{C}$, honey bees shift from discontinuous, convective ventilation to continuous, diffusive ventilation. In the experiment with Triepeolus sp (V8) under near-natural conditions, discontinuous resting ventilation stopped when the temperature fell below $9^{\circ} \mathrm{C}$ and resumed when the morning temperature reached approximately $10^{\circ} \mathrm{C}$ again (see fig 7 ). The nightly temperatures in the areas where these bees occur naturally can reach such values. The temperature in the nest burrows of Anthophora remains higher than the ambient air temperature and thus very likely above the 'chill coma' limit. The temperature at which $A$ fulvitarsis enters 'chill coma' is unknown. 


\section{Clamping-on behaviour}

This bizarre posture that Epeolus, Protepeolus and Triepeolus exhibit while resting is dramatically different from the resting postures of Anthophora, Melecta, and honey bees. Clamping-on is an important prerequisite for attaining a state of profound rest. Clamping-on behaviour during rest also occurs in other Hymenoptera, including bees which are not brood parasites.

\section{CONCLUSIONS}

Rest at night in all the bee genera studied to date is characterized by a number of common features which all show that none of these insects becomes rigid during this phase.

However, one conspicuous difference has emerged: only honey bees exhibit large amounts of motility during rest. In particular, their antennae are much more motile than those of the solitary bees. This indicates that active processes occur during the sleep-like state of honey bees. Sleep in mammals is also characterized by active processes (Borbély, 1986; Koella, 1988). We can, at present, only speculate about the biological significance of processes during rest at night in the honey bee. They could be basically related to the complex life style of these social insects. The high ambient temperature in the honey bee hive at night might be a necessary precondition which allows complex physiological processes to occur (eg, alternation between antennal movements and antennal immobility; changes in muscle tone, reaction threshold, and neuronal activity).

Those solitary bees which clamp on to twigs at night rest in a very different way than honey bees. The profound rest exhibited by these solitary bees could be a torpor-like condition. Conservation of energy is probably much more important for these animals than for honey bees. The type of nightly rest shown by those species of solitary bees which spend the night in burrows could occupy a position somewhere between these 2 extremes.

\section{ACKNOWLEDGMENTS}

I thank the Deutsche Forschungsgemeinschaft (Program SFB 45) and the late O SchulzKampfhenkel (founder of the biological research station Quinta de Sao Pedro, Portugal) for generous financial support. A Pircher and P Westrich provided invaluable help in Portugal, as did W Sherbrooke, Director of the American Museum of Natural History's Southwestern Research Station, Portal, and J Rozen and $\mathrm{H}$ Spangler in Arizona. $G$ Bayer patiently prepared the figures and typed the manuscript. I thank her and the numerous students who participated in the data evaluation. $\mathrm{H}$ Niemetz constructed some of the experimental apparatus. My wife, Jana Steiner-Kaiser, translated the manuscript, and contributed critical discussions and practical support throughout this project. Two anonymous referees made valuable suggestions for improving the manuscript.

Résumé - Repos nocturne chez quelques abeilles solitaires (Hymenoptera, Apoidea). Comparaison avec l'état proche du sommeil chez l'abeille domestique (Apis mellifera L). Les abeilles solitaires étudiées passent la nuit dans la nature, agrippées par les mandibules à des plantes sèches (Epeolus, Tripeolus, Protepeolus, voir fig 1) ou dans des nids creusés dans des falaises de loess (Anthophora fulvitarsis et le parasite de son couvain Melecta tuberculata). Les insectes ont été capturés sur des fleurs ou à l'entrée des nids. Leur comportement a été ensuite enregistré avec une caméra vidéo sensible à l'infrarouge en laboratoire, en conditions constantes et à l'obscurité totale. La comparaison des résultats avec ceux obtenus chez l'abeille domestique (Kaiser, 1988) montre des similitudes aussi bien que des 
différences. Similitudes : les abeilles domestiques comme les abeilles solitaires possèdent des lieux spécifiques de repos. Pendant la nuit la durée des périodes de repos (absence de toilettage et de mouvements corporels amples) augmente (figs 4, 5, 6 et 8 ), alors que le rythme respiratoire diminue (figs $3,4,7$ et 8 ; tableau I) et que la tension de certains muscles est réduite (figs 2 , 3,5 et 6 ). Quand le repos se prolonge, les antennes prennent une position caractéristique (figs $2,5 \mathrm{~B}, 6$ et 7 ). Ces phénomènes indiquent un approfondissement progressif du repos au cours de la nuit, car ils s'accompagnent chez l'abeille domestique d'une élévation du seuil de réaction. Différences: la motilité du corps et des antennes au cours du repos nocturne est beaucoup plus réduite chez les abeilles solitaires que chez les abeilles domestiques. Les espèces qui s'accrochent par les mandibules sont particulièrement calmes sans être immobiles. La durée du repos dépend beaucoup des facteurs externes, en particulier de la lumière. Tandis que les abeilles domestiques et Anthophora sont déjà actives avant le lever du soleil ou encore après le coucher, un individu Epeolus étudié en conditions naturelles, ainsi qu'un individu Triepeolus (fig 7) n'ont quitté leur emplacement de repos que lorsque les rayons du soleil l'ont touché directement. L'abeille domestique se distingue par le fait qu'elle se protège du «coma" dû au froid en passant la nuit dans la ruche chaude. La température élevée de la ruche pourrait être la condition nécessaire pour qu'aient lieu, durant l'état proche du sommeil, les processus complexes qui s'expriment avant tout par l'alternance du repos et du mouvement des antennes et par les modifications du tonus musculaire, du seuil de réaction et de l'activité neuronale. Le sommeil des mammifères se caractérise lui aussi par des processus actifs. Chez les abeilles solitaires qui passent la nuit dehors et s'agrippent par les mandibules, la nécessité d'économiser l'énergie contraint à un état proche de la torpeur. Le type de repos nocturne des abeilles qui passent la nuit dans des trous pourrait représenter un intermédiaire entre les 2 extrêmes.

\section{Apoidea / abeille solitaire / Apis melli- fera / sommeil / repos nocturne / phy- siologie du comportement}

\section{Zusammenfassung - Die Nachtruhe einiger Solitärbienen: ein Vergleich mit dem schlafähnlichen Zustand von} Honigbienen. Die untersuchten Solitärbienen übernachten in der Natur festgebissen an trockenen Pflanzen (Epeolus, Triepeolus, Protepeolus, siehe auch Abb 1) oder in Bruthöhlen in Lößwänden (Anthophora, die die Höhlen gräbt, und ihr Brutparasit Melecta). Die Tiere wurden an Blüten oder vor den Bruthöhlen gefangen; ihr Verhalten wurde dann im Labor unter konstanten Bedingungen und bei völliger Dunkelheit mit einer infrarotempfindlichen Videoanlage registriert. Die Ergebnisse wurden mit den Befunden von Honigbienen (Kaiser, 1988) verglichen und sowohl Ähnlichkeiten als auch Unterschiede gefunden. Ähnlichkeiten: Sowohl Honigbienen als auch die Solitärbienen haben spezifische Ruheorte. Während der Nacht nimmt die Dauer der Ruhe-Episoden (Abwesenheit von Putzen und größeren Körperbewegungen) zu (Abb 4, 5, 6, 8), während die Atmungshäufigkeit abnimmt (Abb 3, 4, 7, 8; Tabelle I) und die Spannung bestimmter Muskeln sich verringert (Abb 2, 3, 5, 6). Bei längerer Ruhe nehmen die Antennen eine charakteristische Haltung ein (Abb 2, $5 B, 6,7)$. Diese Phänomene deuten auf eine allmähliche Vertiefung der Ruhe im Verlauf der Nacht hin, denn bei Honigbienen werden sie von Erhöhungen der Reaktionsschwelle begleitet. Unterschiede: Die Bewegungshäufigkeit des Körpers und der Antennen ist während der nächtlichen Ruhe der untersuchten Solitärbienen viel geringer als bei Honigbienen. Die sich fest- 
beißenden Arten sind besonders ruhig, aber nicht starr. Bei diesen ist die Dauer der Ruhe sehr stark von exogenen Faktoren abhängig, vor allem von Licht. Während Honigbienen und Anthophora schon vor Sonnenaufgang und noch nach Sonnenuntergang fliegen, verließen ein im Freien untersuchter Epeolus sowie ein Triepeolus (Abb 7) ihren Ruheplatz erst, als sie von direktem Sonnenlicht getroffen wurden. Die Honigbiene zeichnet sich dadurch aus, daß sie nachts im warmen Stock vor Kältestarre geschützt ist. Die hohe Stocktemperatur könnte die Voraussetzung für die komplexen Vorgänge während des schlafähnlichen Zustands dieser Tiere sein, die sich vor allem in dem immer wiederkehrenden Wechsel zwischen Antennenruhe und Antennenbewegung und in Änderungen von Muskeltonus, Reaktionsschwelle und neuronaler Aktivität äußern. Auch der Schlaf der Säuger ist durch aktive Prozesse gekennzeichnet. Bei den im Freien übernachtenden, sich festbeißenden Solitärbienen könnte die Notwendigkeit, Energie einzusparen, den torpor-ähnlichen Zustand erzwingen. Die Art der nächtlichen Ruhe der in Höhlen übernachtenden Bienen könnte eine Mittelstellung zwischen diesen beiden Extremen darstellen.

\section{Apoidea / Solitärbiene / Apis mellifera / Nachtruhe / Schlaf / Verhaltensphysio- logie}

\section{REFERENCES}

Borbély AA (1986) Secrets of Sleep. Basic Books, New York, USA

Fiebrig K (1912) Schlafende Insekten. Jena Z Naturwiss 48 (NF41), 315-364

Hess WR (1926) Die Temperaturregulierung im Bienenvolk. $Z$ Vergl Physiol 4, 465-487
Kaiser W (1988) Busy bees need rest, too. Behavioural and electromyographical sleep signs in honeybees. J Comp Physiol A 163, 565-584

Kaiser W (1990a) Wie solitäre Bienen die Nacht verbringen. Verh Dtsch Zool Ges 83, 616-617

Kaiser W (1990b) The behaviour of solitary bees at night. In: Brain-Perception-Cognition. Proc 18th Göttingen Neurobiology Conference (N Elsner, G Roth, eds), Thieme, Stuttgart, Germany, USA, 64

Kaiser W, Steiner-Kaiser J (1983) Neuronal correlates of sleep, wakefulness and arousal in a diurnal insect. Nature (Lond) 301, 707-709

Kaiser W, Steiner-Kaiser J (1991) Sleep in insects - A comparison of the nightly resting state in social and solitary bees. Sleep Res 20A, 223

Koella WP (1988) Die Physiologie des Schlafes. Eine Einführung. Fischer, Stuttgart, Germany

Lighton JRB, Lovegrove BG (1990) A temperatureinduced switch from diffusive to convective ventilation in the honeybee. J Exp Biol 154, 509-516

Rau $P$ (1938) Additional observations on the sleep of insects. Ann Entomol Soc Am 31, 540-556

Rau P, Rau N (1916) The sleep of insects; an ecological study. Ann Entomol Soc Am 9, 227-274

Sauer S, Kaiser W (1995) Pollen foragers of the honey bee (Apis mellifera carnica $L$ ) rest in the hive at night. In: Learning and Memory. Proc 23rd Göttingen Neurobiology Conference ( $\mathrm{N}$ Elsner, R Menzel, eds), Thieme, Stuttgart, Germany, 253

Schremmer F (1955) Beobachtungen über die Nachtruhe bei Hymenopteren, insbesondere die Männchenschlafgesellschaften von Halictus. Österr Zool Z6, 70-89

Schremmer F (1961) Aus dem Nachtleben der Insekten. Der Mittelschullehrer und die Mittelschule, $3 / 4$

Stone GN (1993) Endothermy in the solitary bee Anthophora plumipes: independent measures of thermoregulatory ability, costs of warm-up and the role of body size. J Exp Biol 174, 299-320

Tobler I (1983) Effect of forced locomotion on the restactivity cycle of the cockroach. Behav Brain Res 8, $351-360$

Tobler I (1984) Evolution of the sleep process: a phylogenetic approach. In: Sleep Mechanisms (AA Borbély, JL Valatx, eds) (Exp Brain Res, Suppl vol 8), Springer, Berlin, Germany, 207-226

Tobler I, Neuner-Jehle M (1992) 24-h variation of vigilance in the cockroach Blaberus giganteus. J Sleep Res 1, 231-239

Westrich P (1989) Die Wildbienen Baden-Württembergs, 2 Bd, Ulmer, Stuttgart, Germany 